Medical Research Council Metabolic Reactions Research
Unit

The Medical Research Council is to establish, in 1964, a Metabolic Reactions Research Unit under the honorary direction of Prof. E. B. Chain in the new Department of Biochemistry, which is at present under construction at the Imperial College of Science and Technology, London. The Unit's programme of research will be concerned with the problems of metabolic reactions in the tissues of higher animals, including man, and in micro-organisms. The main subjects of study will be the mode of action of certain hormones, patterns of metabolic pathways in normal and pathological conditions, the metabolism of nervous tissue, the metabolism of mammalian cells in tissue culture, and the isolation and biosynthesis of microbial metabolites of biological interest.

\section{The European Society for Biochemical Pharmacology}

WITH the view of promoting collaboration and personal contacts between scientists engaged in work on the borderline between biochemistry and pharmacology, the European Society for Biochemical Pharmacology has been formed. The constitutional meeting of the Society was held at the Istituto Superiore di Sanità in Rome on February 6. Prof. E. B. Chain, professor of biochemistry, Imperial College of Science and Technology, London, and scientific director of the International Centre for General Biochemistry and Chemical Microbiology, Istituto Superiore di Sanità, was elected president. The Organizing Committee consists of the following: Prof. Z. M. Bacq and Prof. C. Heymans (Belgium); Dr. J. M. Barnes, Dr. E. C. Dalgliesh, Prof. C. E. Dodds, Prof. A. Haddow and Dr. A. Spinks (United Kingdom); Prof. P. Desnuelle, Dr. J. Jacob and Dr. J. Thuillier (France); Prof. P. Holtz, Prof. H. Maske and Prof. R. Pfleger (Germany); Prof. G. B. Marini Bettolo, Prof. A. Di Macco, Prof. S. Garattini, Prof. G. Giacomello, Prof. A. Soldi and Prof. E. Trabuechi (Italy); Prof. B. Uvnas (Sweden); Dr. H. Lanz and Dr. A. Pletscher (Switzerland). Applications for membership and all other enquiries should be addressed to the secretary, Prof. Rodolfo Paoletti, Institute of Pharmacology, University of Milan, Via A. del Sarto 21, Milan. The first general meeting is planned to be held in Milan in spring 1964.

\section{The Research Institute for Advanced Studies}

THE report for 1962 of the Research Institute for Advanced Studies, Baltimore, established in 1955 by the Martin Company "to observe phenomena of Nature and to encourage, promote and support investigations in search of underlying knowledge of these phenomena; to conduct theoretical and experimental studies, to discover the fundamental laws which affect them and to evolve new technical concepts for the improvement and welfare of mankind", rocords good progress by each of its four technical groups-physics, biosciences, mathematics and metallurgy (Pp. 66. Baltimore, Md.: Research Institute for Advanced Studies, 1962). The Mathematics Group has extended its original concentration on non-linear differential equations to the theory of the control and stability of systems. In the biological sciences, investigations in photosynthesis have been extended to embrace studies in cell differentiation, and in metallurgy empirical evidence has been obtained in support of theories of the causes and nature of embrittlement by liquid metals. Lists of publications are included in the sectional reports and there are also lists of technical reports issued by the Institute and of lectures given by its staff and visiting scientists.

\section{The Manchester Public Libraries}

THE 110th annual report of the Libraries Committee of the Manchester Public Libraries for the year ended March 31, 1962, records no significant change in the pattern of use over recent years: fiction reading decreased slightly, serious reading increased, and the use of the reference library increañad by more than 10 per cent (Pp. 39. Manchester: The Public Libraries, 1963). More facilities are required for the serious reader, particularly for students of all ages and types. The greatest difficulty was in retaining staff, and although recruiting new staff was easier than elsewhere the turnover was high. The book stock at the end of the year was 1,186,707 and issues increased to 7,180,191, reference library issues increasing by 226,899 to $2,056,124$. The embarrassing success of the reorganized Technical Library continued and readers totalled 794,440 and the number of items issued 969,122. The largest increase was in patent specifications $(29,272)$, and the Library now holds 89,824 microstats and includes 1,200 titles of scientific and technical periodicals.

\section{Industrial Monuments Survey}

INDUSTRIAL monuments, especially those dating from the Industrial Revolution, are the subject of a national survey now being carried out by the Ministry of Public Building and Works in collaboration with the Council of British Archæology. Mr. Rex Wailes, Davidge Cottage, Knotty Green, Beaconsfield, Bucks., is acting as consultant to the scheme and would welcome details of relevant buildings, plant or equipment which illustrate the beginnings and evolution of industrial and technological processes.

\section{The Council for the Preservation of Rural Wales}

TrE eighteenth annual report of the Council for the Preservation of Rural Wales, Caernarvonshire Branch, covering the year ended March 1963, welcomes the proposal of the Nature Conservancy to include some 6,000 acres of the Snowdon area as a Nature Reserve while protecting existing public access, and also a further area of access agreements between the County Council and landowners, with the introduction of a full warden service (Pp. 26. Ymwlch Fawr, Criccieth: Leslie Bonnet, Acting Hon. Secretary, Council for the Preservation of Rural Wales, Caernarvonshire Branch, 1963). There is increasing concern over the use of land and, for the first time, the Branch opposed the County Planning Authority at a public enquiry at Bangor into the County Council's proposals for the industrialization of the Llandegai valley. Special reference is made to continuing inroads of the Central Electricity Generating Board: both $400-\mathrm{kV}$ lines from Wylfa to Connah's Quay via a sub-station at Pentir, Bangor, and a further line from Pentir to Trawsfynydd have been accepted by the Minister, although the cables across the Glaslyn Estuary and the Aber Gorge are to go underground.

\section{The Cape Provincial Museums}

THE Annals of the Cape Provincial Museums aro published jointly and annually by the five Museums situated at East London, Grahamstown, Kimberley, King William's Town and Port Elizabeth. The current issue (2; August 1962) records the proceedings of a symposium on the causes and problems of animal distribution with special reference to South Africa. Twenty-seven papers are included, and these collectively provide a more comprehensive review of modern zoogeographical research in the sub-continent than has ever been assembled before.

\section{Recent Studies on Feldspars}

Is June 1962 an international symposium on recent advances in the study of feldspars was convened by Prof. T. F. W. Barth of the University of Oslo, with the support of the Scientific Affairs Division of NATO, the U.S. National Science Foundation and the Norges Almenvidenskapelige Forskningsråd. A well-produced volume of the scientific papers presented to this meeting has recently been published for the Norwegian Geological Society, under the editorship of Dr. Olaf Christie (Norsk 